\title{
ESPAÇO PÚBLICO E LAZER: REFLEXÕES A PARTIR DA CIDADE DE UBERLÂNDIA - MG
}

\author{
Fabricio da Mata Lucas \\ Instituto Federal do Triângulo Mineiro, Ituiutaba, MG, Brasil \\ Universidade Federal de Uberlândia, Programa de Pós-Graduação em Geografia, Uberlândia, MG, Brasil \\ fabriciolucas@iftm.edu.br \\ Geisa Daise Gumiero Cleps \\ Universidade Federal de Uberlândia, Instituto de Geografia, Programa de Pós-Graduação em Geografia, \\ Uberlândia, MG, Brasil \\ gdgumiero@ufu.br
}

\begin{abstract}
RESUMO
Este artigo contempla considerações acerca da atividade do lazer e de suas espacialidades na cidade de Uberlândia - MG, com referência nos espaços públicos de lazer. Faz parte de uma pesquisa que objetiva compreender o consumo do espaço público urbano através do lazer. A discussão está estruturada a partir de uma reflexão teórica, que aborda brevemente a produção do espaço urbano, a inserção do lazer com a vida urbana, o consumo do espaço através de sua apropriação pelo mercado e algumas considerações a respeito do espaço público. São levantadas as políticas públicas em execução direcionadas aos espaços livres públicos de lazer, para analisar sua distribuição, juntamente com seus principais equipamentos presentes nos setores da cidade. Observa-se a necessidade de refletir sobre o lazer no âmbito do planejamento urbano, tendo em vista que esta atividade é fundametal para o bem estar do cidadão, sobretudo, nas médias e grandes cidades onde os processos de exclusão social e segregação espacial são mais latentes. Apesar da existência de inúmeras praças e alguns parques públicos, faz-se necessário uma programação de lazer que atenda estes espaços ao longo da cidade, especificamente nas áreas periféricas, além de ampliar sua distribuição, infraestrutura e equipamentos presentes, sobretudo, nas praças públicas.
\end{abstract}

Palavras-chave: Espaço urbano. Políticas públicas. Consumo do espaço.

\section{PUBLIC SPACE AND LEISURE: REFLECTIONS FROM THE CITY OF UBERLÂNDIA - MG}

\begin{abstract}
This article includes considerations activity and its spatiality in the city of Uberlândia - MG, with reference to public leisure spaces. It is part of a research that aims to understand the consumption of urban public space through leisure. The discussion is structured based on a theoretical reflection, which briefly addresses the context of urban space, the insertion of leisure with urban life, the consumption of space through its appropriation by the market and some considerations about public space. The public policies in execution directed to the public free leisure spaces are raised, to analyze their distribution, together with their main equipment present in the sectors of the city. There is a need to reflect on leisure within the scope of urban planning, given that this activity is fundamental for the well-being of the citizen, especially in medium and large cities where the processes of social exclusion and spatial segregation are more latent. Despite the existence of numerous plazas and some public parks, it is necessary to have a leisure program that serves these spaces throughout the city, specifically in the peripheral areas, in addition to expanding their distribution, infrastructure and equipment, especially in public plazas.
\end{abstract}

Keywords: Urban space. Public policy. Space consumption.

\section{INTRODUÇÃO}

O presente texto traz à tona uma discussão em torno da questão do lazer no âmbito do espaço urbano, com foco na relação intrínseca que se estabelece com o consumo do espaço. Para subsidiar esta discussão, acredita-se ser relevante refletir acerca dos espaços públicos, tendo como objetivo compreender o consumo do espaço público através do lazer na cidade de Uberlândia - MG. Temos em 
vista a importância desses espaços na consolidação de atividades culturais e/ou esportivas que contemplem o lazer.

Ao levantar esta discussão, é relevante destacar que a atividade do lazer é comumente associada à prática esportiva. Do ponto de vista teórico, se consolida nas Ciências Sociais e sua interseção com a Geografia pode ser vista a partir da compreensão das espacialidades presentes, sobretudo, ao considerar sua distribuição desigual no interior do espaço urbano. Analisar o espaço e o lugar para se pensar o lazer, bem como as implicações decorrentes de diferentes níveis escalares que influenciam no cotidiano das pessoas torna-se fundamental, sendo que nessa perspectiva, o espaço de análise é o espaço público de livre acesso da cidade em destaque.

Este ensaio contempla uma discussão dividida em quatro partes para expor a temática em questão. Um primeiro ponto teórico aborda sucintamente o espaço urbano, ao considerar sua produção, expansão e articulação em diferentes níveis no mundo atual. Um segundo ponto destaca o lazer e sua inserção na sociedade, buscando levantar entre algumas teorias o significativo vínculo criado em decorrência dos desdobramentos da sociedade industrial, no intuito de identificá-lo com clareza. Um terceiro ponto enfatiza o consumo do espaço, ao pensar na relação de apropriação do mercado sobre o espaço e, consequentemente, sua articulação com o lazer. Um quarto ponto levanta a relevância do espaço público como forma de garantir um uso e consumo mais livre e espontâneo do lazer. Ao mencionar algumas teorias sobre os espaços públicos, busca-se sua articulação com a realidade da cidade de Uberlândia, contando nesse momento com o levantamento das políticas públicas direcionadas ao esporte e ao lazer nos espaços livres públicos da cidade.

No espaço urbano faz-se presente as dinâmicas de produção, circulação e consumo, sendo esta última vital para a reprodução diária da sociedade. Na visão de Villaça (2001) não é o processo de produção, mas sim o de consumo que interessa diretamente ao espaço intraurbano, ou seja, ao contexto da estruturação interna das cidades. No âmbito das dinâmicas de consumo temos a presença do lazer, abordado aqui como elemento central, o qual reflete, sobretudo, o uso de um tempo/espaço determinado - geralmente fora do trabalho - presente de forma desigual no cotidiano das pessoas.

Vivemos em um período no qual a mesma lógica que rege a produção (o trabalho) perpassa e se faz presente no lazer, visto por muitos como uma necessidade que surge a partir do advento da sociedade industrial. A ideia frequente de relaxamento, fruição e qualidade nas ações, muitas vezes é marcada por uma lógica produtivista. O lazer aparece como uma necessidade que deve ser (re) vista e conquistada a qualquer custo. No dizer de Rolnick (2000, p.2), é muito comum atualmente ocorrer,

\begin{abstract}
(...) a luta por um corpo feliz e saudável que requer empenho e esforço tão intensos quanto o trabalho. Não é possível, hoje, imaginar o lazer como uma vivência simples, algo oposto ao trabalho, quando o lazer é reduzido ao consumo de mercadorias de prazer, mercadorias culturais, mercadorias turísticas.
\end{abstract}

As cidades são marcadas pela expansão e descontinuidade territorial, fragmentadas do ponto de vista de seus usos e consequentemente, segregadas, sendo o lazer restrito a espaços e tempos determinados. A conversão dos lugares em um "espaço controlado", a serviço do poder econômico que atua segundo interesses privados, se sobrepõe nas cidades e projetos atuais aos interesses eminentemente públicos. Isso significa que a cidade através de seus diversos espaços públicos sofre com a desvalorização e falta de interesse enquanto expoente do lazer.

É nesse prisma que elencamos nossas reflexões em torno da realidade da cidade de Uberlândia, cidade esta com representativa expansão de sua malha urbana e tamanho demográfico, sendo importante dimensionar as políticas públicas direcionadas ao lazer no que compete aos espaços livres públicos da cidade.

\title{
METODOLOGIA
}

Este ensaio se baseia na coleta de dados a partir de fontes escritas ou secundárias, que incluem tanto a pesquisa teórica, quanto a documental, por meio de informações disponibilizadas pelo poder público municipal.

No caso da pesquisa teórica, são considerados referenciais que auxiliam na questão da produção do espaço urbano, nas teorias do lazer, na sua inserção como um importante elemento presente nas cidades, na relação com o consumo do espaço e nos espaços públicos, com foco em seu uso e 
consumo. Essa discussão teórica, serve de base para relacionar esse contexto à cidade de Uberlândia, referência para o estudo.

O levantamento das políticas públicas municipais, conta com a coleta de informações a partir dos documentos "Caderno Informativo 2018/2019"; "Banco de Dados Integrados 2019" e "Plano Diretor Municipal", revisado no ano de 2017. Ambos estão disponibilizados oficialmente pela Secretaria de Planejamento Urbano, com informações também, das páginas oficiais das Secretarias de Meio Ambiente e Desenvolvimento Urbanístico, Cultura e na FUTEL (Fundação Uberlandense de Turismo Esporte e Lazer). Destaca-se a presença dos espaços/equipamentos públicos de esporte, recreação e lazer, incluindo as praças, parques e os complexos poliesportivos que atendem a população com algum tipo de programação, especificamente, discriminados no Caderno Informativo. A análise do Plano Diretor Municipal se mostra relevante, para visualizar as principais diretrizes que incluem as políticas públicas de lazer no espaço intraurbano da cidade.

\section{O ESPAÇO URBANO}

Pensar o espaço urbano e, por sua vez, sua forma de reprodução material e espacial a cidade, nos faz refletir acerca de relevantes dinâmicas que permeiam, influenciam e são influenciadas por diversos interesses e ações que contemplam a vida em sociedade, através de seus agentes e dinâmicas de produção.

A cidade, na visão de Lefébvre, passou de uma forma geral ao longo de sua história por um processo de sobreposição do valor de troca em contrapartida ao valor de uso (LEFÉBVRE, 2001). No início da urbanização a divisão social do trabalho era relativamente simples, havia um alinhamento entre a cidade e o campo imediato e sob - responsabilidade desta, a escala geográfica da vida política, social e econômica era restrita a uma pequena extensão territorial. Ao longo do tempo o desenvolvimento do modo capitalista de produção engendrou um sistema que se mundializa, onde a realização da vida econômica passou a se estabelecer em escalas cada vez mais abrangentes - incluindo muitos atores como grandes empresas, corporações, políticas de Estado etc. (SPÓSITO, 2011).

Com a intensidade e o aumento no tempo da circulação aumenta a produção do excedente e aumenta a acumulação, fazendo com que a distância espacial se contraia. O imperativo da acumulação produz a concentração da produção e do capital, também gerando uma ampliação do mercado para a realização, consequência disso é o aumento dos fluxos no espaço. (HARVEY, 2005).

A produção do espaço, ao pensar o urbano, impõe a presença de conteúdos e determinações que obrigam a considerar os vários níveis da realidade como momentos diferenciados da reprodução da sociedade. É possível destacar o Estado, o capital com suas estratégias de reprodução (industrial, comercial ou financeiro, por exemplo), além dos sujeitos sociais (que em busca de seu meio de reprodução da vida humana tem o espaço como condição, meio e produto de sua ação). (CARLOS, 2011).

Nesse âmbito, passam a existir no mundo atual interações mais amplas, propiciando a presença de uma rede urbana mais complexa, ocasionada a partir de novas relações entre as cidades, derivadas de aspectos que se referem ao contexto da globalização. A redefinição das relações entre as cidades pode ser refletida a partir da intensificação de tais relações no âmbito das diferentes redes urbanas, e por outro, a possibilidade de interação entre cidades de redes urbanas distintas, ocasionando mudança na qualidade das relações (SPÓSITO, 2011).

É possível prever uma escala de análise das dinâmicas e dos fatores de forma mais ampla, sendo preciso entender o regional, o nacional e o global para se chegar ao local. Spósito (2011) com base em Smith (1998) apresenta ser necessário analisar as mudanças de escala, as quais favorecem as descontinuidades territoriais nas relações, possibilitando a articulação entre escalas e redes que não estão próximas.

Ao mencionar as escalas de análise, é importante conforme Castro (2000) destaca, refletir para além da escala cartográfica, não deixando, no entanto, de considerar sua relevância na análise espacial. Assim, é possível considerar não apenas a organização do espaço, mas também a presença dos fenômenos sociais complexos, onde o que existe são construções teóricas que privilegiam a explicação pertinente a um determinado tipo de escala.

Para Muñoz (2004), as cidades contemporâneas encontram-se cada vez mais inseridas no âmbito de redes que se articulam em escala global. Assim, as cidades são marcadas por um misto entre a

\begin{tabular}{|c|c|}
\hline Caminhos de Geografia & Uberlândia-MG \\
\hline
\end{tabular}


dispersão e a concentração, passíveis de serem caracterizadas como "cidades multiplicadas", agregando novas centralidades, novos fluxos e mobilidade e novas formas de habitar. Torna-se, portanto, cada vez mais perceptível segundo Spósito $(2004$, p.203) a presença de uma constante "expansão territorial urbana (aliada) à descontinuidade dos tecidos urbanos".

Os mecanismos que reforçam esta descontinuidade territorial se associam à segregação espacial. Villaça (2001) destaca que a segregação espacial é característica comum presente principalmente nas grandes cidades brasileiras, sendo possível incluirmos às cidades médias, onde as classes sociais se apresentam devidamente delimitadas e distribuídas no espaço urbano. "O que determina, em uma região, a segregação de uma classe é a concentração significativa dessa classe mais do que em qualquer outra região geral da metrópole" (VILLAÇA, 2001, p.143).

É possível dizer que nas cidades brasileiras os aspectos pertinentes à presença da segregação espacial são fundamentalmente demarcados na questão socioeconômica, sendo fortemente atrelados ao déficit habitacional nas grandes e médias cidades, também levando a pensar que o crescimento urbano compartilha da exclusão social. A estrutura intraurbana revela e reproduz as desigualdades, entendendo-as como a capacidade desigual que cada grupo da sociedade possui em se localizar em determinados espaços - alguns mais privilegiados em relação a outros, em última instância levando à diferenciação socioespacial.

Nesse contexto, reforçamos a relevância do lazer como mais uma espacialidade intrínseca ao espaço e à vida urbana, já que é na cidade que tal atividade se materializa mais significativamente para a vida em sociedade, ou seja, da rua aos grandes equipamentos que favoreçam interação e qualidade nas ações. Desse modo, o acesso democrático a tal atividade é de extrema necessidade para se pensar em reestabelecer o uso das cidades e combater processos excludentes, fundamentalmente através dos espaços públicos.

\section{A EMERGÊNCIA DO LAZER NA SOCIEDADE}

É possível constatar uma ênfase interdisciplinar dada aos estudos do lazer, embora tal discussão tenha sido consolidada no âmbito das Ciências Sociais, especificamente na Sociologia. Parker (1978) é um dos autores que faz referência a essa ênfase interdisciplinar, comentando genericamente a inserção dessa temática em alguns campos de estudo, como, por exemplo, o especial interesse nos fatores espaciais e ambientais por parte de geógrafos sociais.

Na visão de Mascarenhas de Jesus (2003), ao tentar lidar com uma discussão acerca da utilização do tempo livre, possível de se vivenciar o lazer, verifica-se a pouca expressividade presente na literatura geográfica. Assim:

Cabe aos geógrafos, indubitavelmente, o estudo de suas implicações territoriais ou, no sentido mais geral, de sua espacialidade. Entretanto, esta dimensão espacial permanece pouco estudada, pois quando examinamos a trajetória do pensamento geográfico, o que se percebe em seu extenso e mutante repertório temático é justamente a escassez de preocupações quanto ao uso do tempo livre. (MASCARENHAS DE JESUS, 2003, p.8).

A palavra lazer, conforme ressalta Medeiros (1975) e Andrade (2001), vem do latim 'licere' e significa ser lícito, permitido. Podemos pensar a partir desse termo oriundo do latim a ideia de permissão, ou seja, de liberdade, num contexto que liberta o indivíduo de obrigações para desfrutar prazerosamente seu dia.

Com o início da Revolução Industrial (meados do Séc. XVIII), ocorre uma alteração brusca do tempo destinado ao trabalho, com drástico aumento através da padronização e especialização da produção, o que fez o trabalhador se tornar um condutor de máquinas. Em 1825, são iniciadas na Inglaterra as reivindicações dos operários que visavam a redução da jornada de trabalho, no entanto, "o lazer não figurava ainda como reivindicação valiosa por si mesma" (MEDEIROS, 1975, p.26).

Nesse período, Paul Lafargue escreveu o manifesto intitulado 'O Direito à Preguiça'. De acordo com Chauí, esta obra apresenta:

[...] um painel da sociedade burguesa, visando alcançar o ploretariado no nível da consciência de classe e por isso é a crítica da ideologia do trabalho, isto é, a exposição das causas e da forma do trabalho na economia capitalista, ou o trabalho assalariado. (CHAUÍ, 2000, p.23). 
É possível refletir que essa livre interação entre o trabalho e o restante da vida das pessoas, existente em um período anterior ao advento da revolução industrial, é substituída a partir do início da industrialização. Uma das consequências desse processo foi a criação da cidade industrial, através de uma supervalorização do trabalho, consequente divisão do tempo através do relógio e da exploração dos trabalhadores. (LEFÉBVRE, 2001).

Nesse sentido, o lazer é concebido para uma importante vertente defendida por teóricos como o sociólogo francês Dumazedier, por exemplo, como um fenômeno típico da sociedade industrial. O presente autor contesta a visão que concebe a presença do lazer nas sociedades pré-industriais, ao destacar não ser possível acreditar que "(...) a ociosidade dos filósofos da antiga Grécia ou dos fidalgos do Séc. XVI possa ser chamada de lazer. Estes privilegiados da sorte, cultos ou não, faziam pagar sua ociosidade com o trabalho dos escravos, dos camponeses ou dos valetes". (DUMAZEDIER,1999, p.27).

No dizer do autor, o lazer surge como decorrência do avanço da técnica que permitiu a expansão da sociedade industrial. Nesse sentido:

\begin{abstract}
Nas sociedades pré-industriais do período histórico, o lazer não existe tampouco. $\mathrm{O}$ trabalho inscreve-se nos ciclos naturais das estações e dos dias: é intenso durante a boa estação, e esmorece durante a estação má. Seu ritmo é natural, ele é cortado por pausas, cantos, jogos, cerimônias. Em geral se confunde com a atividade do dia (...). Entre trabalho e repouso o corte não é nítido. Nos climas temperados, no decurso dos longos meses de inverno, o trabalho intenso desaparece para dar lugar a uma semi atividade durante a qual a luta pela vida é, muitas vezes, difícil. (...) Esta inatividade é suportada; ela é amiúde associada a um cortejo de adversidades. Evidentemente, não apresenta as propriedades do lazer moderno. (DUMAZEDIER, 1999, p.26).
\end{abstract}

Torna-se evidente, que com a expansão da era industrial e a crescente ascensão da produção em grande escala decorrente dessa fase, o processo de urbanização se intensifica e a vida nas cidades impõe uma divisão cada vez mais voraz no(s) tempo(s) e espaço das pessoas, verificando-se um aumento brusco do período destinado ao trabalho, sendo dicotomizadas as parcelas do tempo no dia a dia.

Segundo Marcellino (2003, p.23-24):

Entre os estudiosos do lazer não há ainda um acordo na forma de entendê-lo, sendo que podemos distinguir pelo menos duas grandes linhas: a que se fundamenta na variável atitude e considera o lazer como um estilo de vida, portanto independente de um tempo determinado; e a que supõe esse tempo, situando-o como "tempo liberado" do trabalho ou como "tempo livre", não só do trabalho, mas de outras obrigações: familiares, sociais, políticas e religiosas, enfatizando a qualidade das ocupações desenvolvidas.

Com base em Marcellino (2003), é possível destacar que essa primeira linha que considera o lazer um estilo de vida ou uma atitude, teve como um de seus grandes representantes o sociólogo David Riesman, o qual previu a possibilidade de momentos de lazer no próprio ambiente de trabalho, desde que exista uma relação de satisfação, através de uma ligação entre o sujeito e a experiência vivida, não fazendo sentido a circunstância de tempo. No entanto:

O lazer encarado apenas como atitude, como estilo de vida, fica na dependência exclusiva da relação da pessoa envolvida com a atitude. E, assim, qualquer atividade poderia ser considerada lazer, até mesmo o trabalho, desde que atendesse a determinadas características, como a escolha individual, e um nível de prazer e satisfação elevados (MARCELLINO, 2000, p.10).

A outra linha teórica, a qual inclui o lazer a um tempo determinado, pode ser considerada a partir da ênfase no uso do tempo livre, frequentemente difundida no Brasil e no mundo. Esta linha teórica se propagou e influenciou inúmeros estudos acerca da temática. Para Dumazedier (2001, p.34), o lazer compreende 0 ,

[...] conjunto de ocupações às quais o indivíduo pode entregar-se de livre vontade, seja para repousar, seja para divertir-se, recrear-se e entreter-se ou ainda para desenvolver sua formação desinteressada, sua participação social voluntária, ou sua livre capacidade criadora, após livrar-se ou desembaraçar-se das obrigações profissionais, familiares e sociais. 
Cabe refletir se realmente existe um tempo absolutamente desvinculado de qualquer tipo de responsabilidade ou necessidade de cunho social, pois mesmo ao usufruir do tempo livre, estamos sujeitos a pensar de forma organizada, carregando tensões acerca de outras demandas cotidianas que ocorreram ou estão por vir. É importante mencionar que a sociedade atual é cada vez mais impulsionada pelo consumo, no tempo livre ou liberado do trabalho, onde é recorrente a indução e vinculação ao consumo do entretenimento, seja através de viagens, filmes, passeios a restaurantes, bares etc.

Para Marcellino (1995, p.131), seria mais correto falar em "tempo disponível", ou seja, concebido, mas não completamente livre após o cumprimento de outras obrigações. Assim, o lazer é definido "(...) como a cultura compreendida no seu sentido mais amplo - vivenciada (praticada ou fruída) no tempo disponível". Torna-se possível refletir acerca de uma cultura que agregue qualidade nas ocupações e atividades desempenhadas, no intuito de considerar atividades que vão além da prática física do lazer, ao também levar em conta sua contemplação e/ou consumo, desde que seja do interesse de cada um.

Pensar na existência de um tempo disponível parece ser mais oportuno, ao levar em conta a possibilidade de usufruir de algo ofertado a partir da desvinculação provisória de outras atividades obrigatórias, incluindo a presença de atitudes que proporcionem prazer nas ações realizadas e nos espaços que são destinados.

Ao entender o "tempo livre" ou "disponível" como o momento ideal para a vivência do lazer, torna-se possível indagar como os cidadãos de diferentes segmentos sociais conseguem utilizar este tempo no seu dia a dia. É necessário mencionar também, a respeito da apropriação do espaço para o lazer, sendo que a própria localização do indivíduo é marcada por entraves ou barreiras que dificultam seu acesso à cidade e a seus equipamentos (culturais, esportivos etc.). Esse cidadão, dotado de direitos em tese e sujeito com frequência a processos excludentes (de ordem econômica e espacial, por exemplo), mesmo com acesso ao tempo liberado das atividades profissionais, dificilmente consegue revertê-lo em tempo para o lazer.

De uma forma geral, é comum atualmente associar o lazer a uma visão funcionalista. Essa abordagem o coloca como uma "válvula de escape" ou assimilador de tensões, no intuito de garantir a manutenção do "status quo", não se verificando uma efetiva intenção em ver o lazer como algo realmente humanizador, como um fim prazeroso em si mesmo. Nesse sentido, torna-se perceptível o interesse em desviar a atenção dos problemas sociais, pessoais e, por que não, socioespaciais. Apresenta-se assim, a ideia do "antilazer", o qual constitui uma construção ideológica que tem como objetivo garantir a ordem, servindo de instrumento de dominação. Para Marcellino (2000, p.49), esse antilazer corresponde a "(...) simples atividades a serem consumidas alimentando a situação alienada".

Padilha (2003) faz duras críticas a uma visão amplamente divulgada atualmente que remete à existência de uma "civilização do tempo livre" ou do "ócio criativo", ao afirmar que devem ficar claras as grandes diferenças existentes nos países capitalistas, sendo presentes em muitos a extrema miséria, violência etc. Não é possível falar em "ócio criativo" em espaços marcados por problemas de toda ordem, onde o trabalho é desenvolvido em sua maioria na informalidade.

É possível destacar que a vivência do lazer atual corrobora para haver uma segmentação do espaço em termos de uso e consumo, onde a presença de elementos associados à revitalização urbana fazemse presentes, criando essas diferenças no espaço geográfico. Nessa perspectiva, ocorre a emergência de um espaço de distração, através de uma necessidade socialmente produzida que pode efetivamente ser apropriada pelo consumidor. Nesse movimento de apropriação, o espaço é convertido em lugar, consequentemente, o espaço para o tempo livre torna-se cada vez mais operado pelo mercado. Todavia, a consciência do sujeito acerca desse contexto já não pode ser atestada com a mesma facilidade, mesmo porque a liberdade do tempo de lazer se opõe de maneira contraditória à necessidade do mercado.

$\mathrm{Na}$ medida em que a publicidade e a cultura de consumo atuam nas sociedades capitalistas como instrumentos que corrompem a arte, a cultura, as necessidades e a própria vida, e na medida em que legitimam a conversão de tudo em mercadoria, elas contribuem para a generalização do processo de reificação ou coisificação. Nesse sentido, o lazer - enquanto atividade a ser realizada num tempo considerado "livre" também é mercadoria nas sociedades regidas pela lógica e racionalidade do capital. Por isso, tempo livre e capitalismo formam um par imperfeito, do ponto de vista do caráter de liberdade atribuído a este tempo. (PADILHA, 2006, p.146-147).

Santos (1987, p.48), destaca que o intenso processo de urbanização, pelo qual as cidades atravessam, proporciona a existência de uma cidade mais coorporativa, onde os grupos com maior ascensão

$\begin{array}{lllll}\text { Caminhos de Geografia } \quad \text { Uberlândia-MG } & \text { v. 21, n. 76 } & \text { Ago/2020 } & \text { p. 231-248 Página } 236\end{array}$


econômica e social se apropriam mais intensamente desta. Assim, "o lazer na cidade se torna igualmente o lazer pago, inserindo a população no mundo do consumo". Ainda segundo o autor, "um resultado da planificação urbana capitalista combinada com o processo especulativo do mercado é a distribuição desigual dos equipamentos de educação e de lazer" (SANTOS, 1987, p.90). Portanto, o lazer se dissemina de forma distinta dentro do espaço, já que o lugar que os indivíduos detêm na cidade e até no campo, torna-se um dado fundamental para a reprodução das relações sociais desiguais.

O espaço destinado às diferentes atividades, sejam elas contemplativas ou ativas/ esportivas deve vislumbrar o princípio do prazer e da fruição, considerando a liberdade de escolha nas ações desenvolvidas por cada indivíduo. No entanto, é inegável que tanto o aproveitamento do tempo quanto dos espaços, materializados nos lugares do lazer se tornaram cada vez mais apropriados pelo mercado e pelo consumo, com a presença de atividades mais comuns a determinadas formas de confinamento da sociabilidade. É nesse prisma que abordaremos na sequência o consumo do espaço, no intuito de compreender como os lugares são convertidos por uma lógica hegêmonica que se apropria, sobretudo, do lazer, transformando-o a partir de um padrão comum.

\section{O CONSUMO DO ESPAÇO E A RELAÇÃO COM O LAZER}

Diante das considerações apresentadas, ao refletir acerca da atividade do lazer no mundo atual, fica evidente sua importância tanto prática quanto contemplativa para a sociedade. Possibilidade indispensável de relaxamento, formação intelectual, atividades físicas e busca pelo prazer individual. Propiciado na vida moderna a partir da disposição de um tempo específico, tal atividade encontra-se cada vez mais permeada pela consumação de signos, incluindo objetos, momentos prazerosos e sonhos que se relacionam permanentemente com o cotidiano de cada um, mesmo que nem todos o vivenciem efetivamente.

As atividades desenvolvidas vinculam-se cada vez mais com o perfil socioeconômico das pessoas e sua capacidade de deslocamento espacial, ou seja, reflete as potencialidades em relação à utilização e consumo no/do espaço. Nesse sentido, a forte vinculação com as relações de mercado faz-se presente, relacionando a possibilidade do desfrute do tempo disponível a um negócio, mais comum ainda ao se tratar de períodos mais longos como as férias, articulando-se com a ascensão da atividade turística.

O espaço geográfico e sua reprodução enquanto totalidade resulta da reprodução das relações sociais e espaciais, produzindo inúmeras novas contradições inerentes à extensão do capitalismo. Tais contradições permeiam a instalação de espaços que atendam à atividade do lazer nas cidades, desde a instalação de espaços específicos, dotados de equipamentos públicos (como praças e/ou parques esportivos), que muitas vezes são concentrados em determinadas localizações sem atender a setores densamente povoados nas periferias. O mesmo pode ser pensado acerca das ações revitalizadoras que refuncionalizam determinadas áreas, criando espaços de consumo e lazer que, por outro lado, excluem muitos segmentos sociais.

Ao levar em conta essa totalidade que representa o espaço geográfico, torna-se possível compreendêlo a partir da presença de objetos (naturais e artificiais), atores sociais, ações e conflitos que se interrelacionam e se realizam num constante movimento. Nas palavras de Santos (1988), corresponde a "(...) um conjunto de objetos e de relações que se realizam sobre estes objetos". O espaço se produz a partir do "resultado da ação dos homens sobre o próprio espaço, intermediados pelos objetos, naturais e artificiais". (SANTOS, 1988, p.71).

As ações e decisões tomadas em âmbito geral são cada vez mais controladas a partir de outras escalas (mundiais ou globais, por exemplo) e alheias ao cotidiano da sociedade. No entanto, não pode ser negligenciado que é na escala do lugar que as demandas de âmbito mundial ganham "corpo", impondo adaptações e sendo adaptadas constantemente para manter o ciclo de reprodução. A manifestação das práticas socioespaciais que se aproximam do cotidiano e resultam na produção/ reprodução do espaço social diário, fazem-se presentes no lugar.

Assim, para Carlos (2007a, p.41), "o lugar, (...), liga-se de modo inexorável à realização da vida como condição e produto do estabelecimento das relações reais indispensáveis a ela, mas a produção da vida e do lugar revela a necessidade de sua reprodução continuada". Ainda nesse contexto, a ideia de reprodução é fundamental para a compreensão desse processo, sendo que a noção de produção se relaciona à apropriação, esta última indica que as relações ocorrem no plano do morar, englobando os 
momentos de lazer, trabalho, vida privada e o sentido do dinamismo entre as necessidades e os desejos que pautam a reprodução da vida.

A noção acerca do cotidiano revela-se como mais um elemento importante de análise, pois este se refere às ações que permeiam diária e corriqueiramente a vida em uma dada fração do espaço. Como decorrência da reprodução do capital, um novo espaço se cria em escala mais ampla (mundial) que transcende o lugar, impondo a formação de um espaço homogeneizante, com usos cada vez mais controlados e comuns. Carlos (2007a) aponta que:

O plano da vida cotidiana - no lugar - como produto direto da reprodução do capital, revela o mundo da mercadoria que se generaliza invadindo e colonizando a vida cotidiana, mediando as relações sociais e redefinido-as a partir da criação de modelos e padrões estipulados pelo consumo da mercadoria enquanto símbolo definidor das relações. (CARLOS, 2007a, p.43).

A padronização de gostos, marcas e principalmente, a forma de usar o seu momento de lazer torna-se mediada por um controle que já está implícito às ações de cada um, que tende a direcionar determinados padrões, os quais servirão de referência para os variados segmentos sociais. O culto à estética (corpo perfeito - "sarado") associa-se, por exemplo, ao consumo de vestuário, espaços especializados e dietas alimentares rigorosas que se relacionam ao ideário de "saúde perfeita", como indicador de que o indivíduo precisa estar com seu corpo em plena forma para ser visto, seja no clube, na rua, na praia, em uma viagem etc.

Carlos (2007a, p.43) destaca que aceitar as novas condições de existência, implica na "(...) constituição de uma rotina altamente organizada da vida, (que) transforma radicalmente a sociabilidade, empobrecendo as relações sociais na medida em que as relações entre as pessoas passam a ser substituídas por relações mediadas pela mercadoria".

Nesse âmbito, o plano da vida cotidiana, vivenciado no lugar, deixa de apresentar características espontâneas e improvisadas vinculadas ao contato direto entre as pessoas, sobretudo, no que compete ao uso do tempo livre ou disponível nas médias e grandes cidades. Isso significa que muitas relações de vizinhança, como 'sentar-se na calçada para conversar com vizinhos' e as 'brincadeiras de crianças na rua', por exemplo, tornam-se absolutamente incomuns, resistindo ainda alguns lampejos desses contatos em alguns bairros específicos (onde talvez exista a presença de várias gerações convivendo), nas periferias pobres e nas pequenas cidades.

O mais comum, atualmente, é seguir a tendência de um cotidiano controlado, no qual as rápidas mutações transformam e destroem os referencias da vida cotidiana. O cotidiano deixou de ser rico de possibilidades - subjetividades - e se converte em objeto de organização social.

Lefébvre (1984, p.115), ao tecer suas críticas, ressalta que o imaginário em relação à prática cotidiana - vista como coação e apropriação - tem uma função: “(...) enmascarar el predomínio de las coacciones, la escasa capacidad de apropriación, la agudeza de lós conflictos y de lós problemas reales".

Isso corrobora o entendimento acerca do controle mencionado, que conta com inúmeros agentes "doutrinadores" que camuflam os conflitos latentes e atuam para impor os comandos do sistema econômico vigente. O papel da mídia e especificamente, sua vinculação ao poder da televisão é fundamental no âmbito da vida cotidiana. Com essa programação que se instala e comanda as atitudes e ações presentes no dia a dia, é notória a diminuição da comunicação dentro do espaço da própria casa, com a presença de um espaço/tempo mais abstrato, ausente de formas concretas de vida e com experiências mais ilusórias do que reais.

É nessa lógica que o espaço de consumo se converte em consumo do espaço, comprovando a presença de uma lógica de mercado que se apropria e controla todos os momentos na vida do indivíduo, inclusive do 'ócio' ou tempo de lazer. Essa lógica será mais impactante em escalas mais amplas (do regional até o mundial), com a presença da atividade turística e da criação de seus "simulacros". Na produção atual do espaço, se constitui por um lado, um processo de mundialização dos valores de uma sociedade urbana que impõe a homogeneização do espaço, mas ao mesmo tempo, acarreta em fragmentar o espaço e o indivíduo. (CARLOS, 2007b). O espaço urbano é substancialmente fragmentado (fatiado) em pedaços para diferenciar os padrões dos grupos sociais que o habitam, tanto em termos de moradia, quanto de acesso a equipamentos necessários para a reprodução da vida.

No que tange à essa homogeneização, tal processo desenvolve um novo espaço baseado na não identidade e não - pertencimento, chamado de "não - lugar". Esse não - lugar representa a fração do espaço sem nenhum tipo de referência pessoal e afetiva. No sentido antropológico de Augé, seria 
aquele não identitário, não relacional e não histórico, como as auto-estradas, aeroportos e supermercados, vistos como lugares de passagem e não de fixação dos indivíduos. (AUGÉ, 1994 apud CARLOS, 2007b). Esses pontos específicos do espaço, ausentes de relações e referências com seus usuários relacionam-se à ideia da "urbanalização" mencionada por Muñoz (2004).

Com relação ao turismo, os não - lugares representam simulacros, ou simulações de um mundo que efetivamente, não é o real. A presença de grandes hotéis de luxo, resorts, restaurantes, vias e até espaços públicos altamente especializados indicam apropriadamente esse contexto. Nesses exemplos, propaga-se a ideia de um espaço global, comum a qualquer lugar que inibe as características do local.

Carlos (2001, p.176), ao atentar para essa questão, ressalta que "a reprodução espacial, voltada para o reprodutivo e para o repetitivo, produz simulacros no espaço, consumidos enquanto espaços de turismo e lazer, enquanto simulação de um espaço novo - na realidade, um espaço fragmentado, reduzido e limitado pelas necessidades da acumulação".

Assim é que surgem as novas formas urbanas, as quais reforçam uma lógica que conduz a uma seleção programada dos lugares, onde esses são "(...) escolhidos e retirados da dinâmica cotidiana e orgânica da cidade como lugar". (DAMIANI, 1997, p.46).

É possível dizer que as horas de não trabalho destinadas ao desfrute do lazer estão fortemente vinculadas às regras do mercado, criando uma relação mais artificial entre o cidadão (usuário) e os espaços presentes, gerando uma falsa ideia de apropriação dos lugares. A sociedade atual vem sendo marcada por forte conotação ao consumo, e aos padrões esteticamente estabelecidos pela mídia que influenciam no lazer dos centros urbanos. No que tange à sociedade moderna, o lazer surge como uma necessidade que permanece até os dias atuais, tal necessidade perde muito no passar do tempo o seu caráter espontâneo emaranhado no cotidiano das pessoas, tornando-se cooptado na visão de Carlos (2007b) pelo desenvolvimento da sociedade de consumo, que tudo que toca transforma em mercadoria, tornando o homem num elemento passivo.

Barbosa (2004) considera que para uma determinada vertente de pensamento, a sociedade de consumo engloba uma visão que ultrapassa a ideia de consumo de massas e para as massas, incluindo o critério da individualidade na escolha dos bens a consumir, passando a existir uma verdadeira cultura de consumo. A autora apresenta que tal expressão é vista como um rótulo recorrente e utilizado na contemporaneidade para se referir a um tipo de sociedade, na qual o critério da individualidade passa a comandar a escolha dos bens a consumir. Nesse contexto, verifica-se uma mudança no padrão de consumo familiar para o individual, bem como de uma passagem do consumo de "pátina" (ligado à tradição) para a "moda", caracterizada pela efemeridade e individualidade.

Ao retornar à questão espacial e articular com o acesso do cidadão ao lugar, entendemos que as relações de consumo se ampliaram de forma latente, ao ponto de não ser deixada de lado nenhuma fração do espaço que possa interessar ao processo de reprodução do capital. Nesse processo, tudo que possamos pensar se torna consumível, do lugar ao espaço global, acarretando em um aumento exponencial desse consumo, ao ponto do cidadão (dotado de direitos em tese) ser associado a um mero usuário.

Para Santos (1987, p.35), "a glorificação do consumo se acompanha da diminuição gradativa de outras sensibilidades, como a noção de individualidade que, aliás, constitui um dos alicerces da cidadania”, revelando um individualismo feroz e sem fronteiras.

Ao se referir à escala intraurbana, é possível ter em mente que no local, a análise do consumo do espaço se acirra na relação contraditória que envolve a separação entre espaços públicos e espaços privados. Cabe repensar acerca das possibilidades de ver a esfera do lazer como capaz de gerar a apropriação dos espaços - dos lugares do lazer - por parte das pessoas, sobretudo, no que tange aos espaços públicos. A seguir, abordaremos algumas noções que envolvem o entendimento destes espaços e como vêm sendo organizados pelo poder público no espaço intraurbano de Uberlândia.

\section{ESPAÇO PÚBLICO E LAZER EM UBERLÂNDIA}

Ao se referir ao contexto dos espaços públicos, torna-se possível associar sua importância ao acesso democrático à cidade. Este espaço se materializa a partir de diferentes formas urbanas encravadas no interior das cidades, sendo historicamente visto como lócus do encontro, da discussão política, da busca pelo espetáculo, do contato com elementos da natureza etc. Podemos elencar alguns desses espaços que possuem vínculo com as atividades de lazer. De um lado, existem os inúmeros prédios ou repartições públicas com usos controlados, como museus, teatros, bibliotecas etc. Por outro lado, 
estão presentes os espaços livres e abertos, como praças, largos e parques, por exemplo. Ambos os casos podem ser caracterizados através de seu uso público, com algumas restrições de uso e não de acesso, além de se localizarem em áreas mantidas pelo poder público, sendo fundamental servirem ao amplo acesso à população, sem distinção.

É importante mencionar que existe uma variedade de espaços materializados que se caracterizam como públicos, havendo a necessidade de distingui-los de acordo com os seus usos e normas de funcionamento. Gomes (2002, p.165-166), destaca que é o resultado de uma ação contratual com o espaço que traduz a ideia do espaço público, sendo que este espaço "(...) se opõe assim ao conceito de espaço coletivo, fundado sobre a ideia de uma coletividade estruturada por uma identidade, ela mesma originária de uma suposta afinidade repartida de maneira uniforme sobre o espaço". O que constrói o espaço público é a obediência às leis e limites, é onde a individualidade se expressa dentro de um universo forçosamente plural.

O autor reforça que os atributos de um espaço público são aqueles que têm relação direta com a vida pública. Pode ser "(...) simultaneamente o lugar onde os problemas se apresentam, tomam forma, ganham uma dimensão pública, (...), são resolvidos". (GOMES, 2002, p.160). Alerta que um dos grandes problemas da nossa sociedade foi o de transformar o público em passivos espectadores, algo que em nosso entendimento vai de encontro com a homogeneização das práticas cotidianas, as quais resultam de uma fragmentação, tanto do espaço quanto do indivíduo enquanto ator social. Nessa perspectiva, o autor atribui a ideia do recuo da cidadania, cada vez mais preponderante nos espaços públicos com a menor frequência e interação social. Isso pode ser pensado, sobretudo, quando se reflete acerca da prática e contemplação do lazer.

Podemos facilmente relacionar as mudanças na imagem da cidade, diferente daquela construída nos primeiros tempos da modernidade, (...). Ela é hoje concebida como fragmentada, como soma de parcelas mais ou menos independentes, havendo uma multiplicação de espaços que são comuns, mas não públicos; há um confinamento dos terrenos de sociabilidade e diversas formas de nos extrairmos do espaço público (telefones celulares, fones de ouvido, etc.), os modelos de lugares se redefiniram, shopping centers, ruas fechadas, paredes 'cegas' etc. (GOMES, 2002, p174).

Para Serpa (2007, p.15), "na análise do espaço público urbano, forma e conteúdo são, (...) indissociáveis, e uma discussão sobre o tema passa (...) pela difícil articulação entre aspectos que dão concretude à esfera pública urbana e aqueles de cunho mais abstrato, que denunciam o caráter intersubjetivo". Uma abordagem nesse prisma inclui a noção de cidadania, a ação política e a análise da acessibilidade.

A noção de acessibilidade (com forte vínculo geográfico) deve corresponder a algo que vá além do acesso físico e material, mas também incluir os aspectos simbólicos e, consequentemente, possibilitar a apropriação social dos espaços públicos urbanos. O mais perceptível hoje, é que mesmo em espaços abertos e de uso coletivo, ocorre uma apropriação seletiva e diferenciada dos espaços de acordo com o interesse dos grupos sociais presentes. Nesse sentido, (re) pensar essa apropriação do espaço público parece ser um grande desafio, já que as formas urbanas são cada vez mais atreladas a modelos comuns a qualquer lugar. Ocorre, todavia, uma crescente expansão de outros espaços que são comuns e geralmente privados, que em nome da segurança e conforto tornam-se atrativas opções de lazer.

Ao pensar na cidade de Uberlândia, podemos fazer menção ao termo definido por Santos (1993), enquadrando esta como uma grande cidade média. Tal termo foi considerado por outros autores que pensaram a realidade da cidade, entre eles, Soares et al.(2004) e Bessa (2005), sendo que ambos destacam a importância regional da cidade e seu papel na rede urbana que se encontra inserida. Esta cidade mantém relações constantes e duradouras com seu espaço regional, com o campo modernizado do entorno e com centros urbanos de hierarquia superior, como, por exemplo, as metrópoles.

Ao longo do tempo, a cidade passa por constante expansão do seu tecido urbano, seguindo a lógica de contínua extensão horizontal, produção de novas centralidades e fragmentação territorial. Isso ocorreu, por um lado, respaldado no planejamento mais harmônico de alguns bairros, com a presença de boa infraestrutura, áreas verdes e a concentração de condomínios de médio a alto padrão em determinados eixos, como no Setor Sul, por exemplo. Por outro lado, essa expansão também ocorre de forma precária, proporcionando o adensamento de muitos bairros periféricos com pouca infraestrutura, compostos por conjuntos habitacionais populares com alta densidade demográfica e até por submoradias, o que revela a presença constante da segregação espacial.

No que se refere à presença dos espaços públicos, observa-se em Uberlândia um processo de transformação em seu uso que foi comum em muitas cidades brasileiras ao longo do Séc. XX. Até os anos 1990, mesmo com uma clara separação entre os locais frequentados pelos indivíduos de diferentes camadas sociais, os espaços públicos das ruas, praças, etc. funcionavam como locais de 
encontro e convívio entre os grupos sociais. A partir dessa época, o surgimento dos shopping centers e dos condomínios fechados, assim como a sofisticação dos clubes de lazer, contribuíram para a estratificação social do espaço urbano. Isso gerou o abandono do centro pelas elites, que passaram a morar e a buscar outras áreas da cidade para suas atividades de lazer e compra. Além disso, o desenvolvimento dos meios de comunicação permitiu que, cada vez mais, a vida social ocorresse no ambiente doméstico (FONSECA, 2005).

Ao enfatizar a presença dos espaços livres na cidade (possíveis de uso através do lazer), Cocozza e Oliveira (2013) destacam que dois aspectos podem ser levantados: o primeiro deles refere-se à perda da sua condição qualitativa, seja pela esfera pública e pelo lócus identitário da vida cotidiana, assim como a do seu papel na organização do tecido urbano. Algumas praças estão presentes apenas no papel, não existindo um pensamento urbanístico que as valorize, fato comum nas regiões periféricas, onde a rua ainda exerce esse papel de convívio no espaço público. O segundo aspecto levantado refere-se à questão do crescimento econômico e populacional, o qual faz com que a cidade priorize intervenções no sistema viário para o transporte individual, no sistema de abastecimento de água e energia, pouco se pensando acerca do sistema de espaços livres urbanos.

Percebe-se em linhas gerais, uma perda de valor dos espaços públicos e do seu significado em função da expansão de clubes privados, condomínios e dos próprios Shopping Centers, vistos como espaços coletivos voltados para o consumo e lazer, sob o viés de segurança e comodidade. Esse contexto não corresponde a uma exclusividade da cidade de Uberlândia, fato comum em outras grandes cidades, tanto nas metrópoles, quanto nas inúmeras cidades médias em expansão no território brasileiro. Para os segmentos sociais mais populares e desprovidos de recursos, a disposição física e/ou financeira para a atividade do lazer se restringe a um segundo plano, isso se deve dentre outras medidas, aos grandes deslocamentos diários entre a casa e o local de trabalho, por exemplo.

A seguir, apresentamos imagens de dois espaços livres públicos significativos na paisagem urbana da cidade através das Figuras 1 e 2.

Figura 1 - Vista Parcial do Parque do Sabiá-2018.

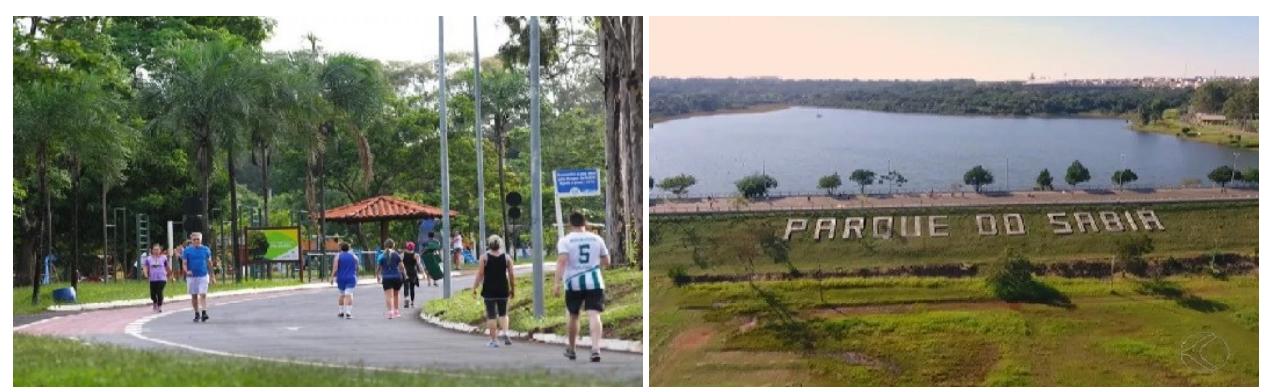

Fonte - g1.globo.com. Acesso em 01/09/2019.

Figura 2 - Praça Sérgio Pacheco (1976) / Praça Sérgio Pacheco (2019).
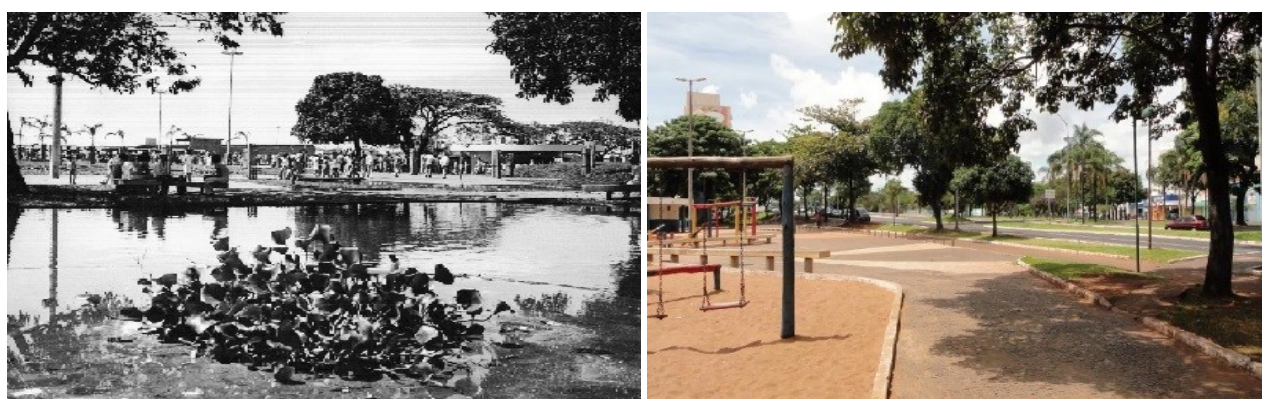

Fonte - museuvirtualdeuberlandia.com/ youtube.com. Acesso em 01/09/2019.

A Figura 1 identifica um parque municipal considerado "modelo" e até referência turística na cidade de Uberlândia. Este parque (Parque do Sabiá) é frequentado principalmente por praticantes de atividades físicas ao longo da semana, prioritariamente por segmentos de médio padrão de consumo e, em contrapartida, por habitantes e famílias de bairros mais populares em busca de lazer nos finais de semana. Na Figura 2 temos a presença de uma praça localizada na área central da cidade (Praça Sérgio Pacheco). Inaugurada nos anos de 1970, esta praça passa por perceptíveis mudanças no seu 
uso ao longo do tempo, sendo ainda frequentemente utilizada para o lazer, contando com alguns equipamentos específicos, como o parque infantil, por exemplo.

Apresentamos na sequência, alguns dados referentes à disposição dos espaços/ equipamentos livres públicos de esporte e lazer da cidade de Uberlândia. Utilizamos como base, o levantamento realizado no documento Caderno Informativo 2018/2019 disponibilizado pela Secretaria de Planejamento Urbano que se encontra na figura 3 a seguir.

Figura 3 - Parques urbanos, total de praças, praças com equipamentos de lazer e demais equipamentos de recreação e esportes por setor em Uberlândia - 2019.

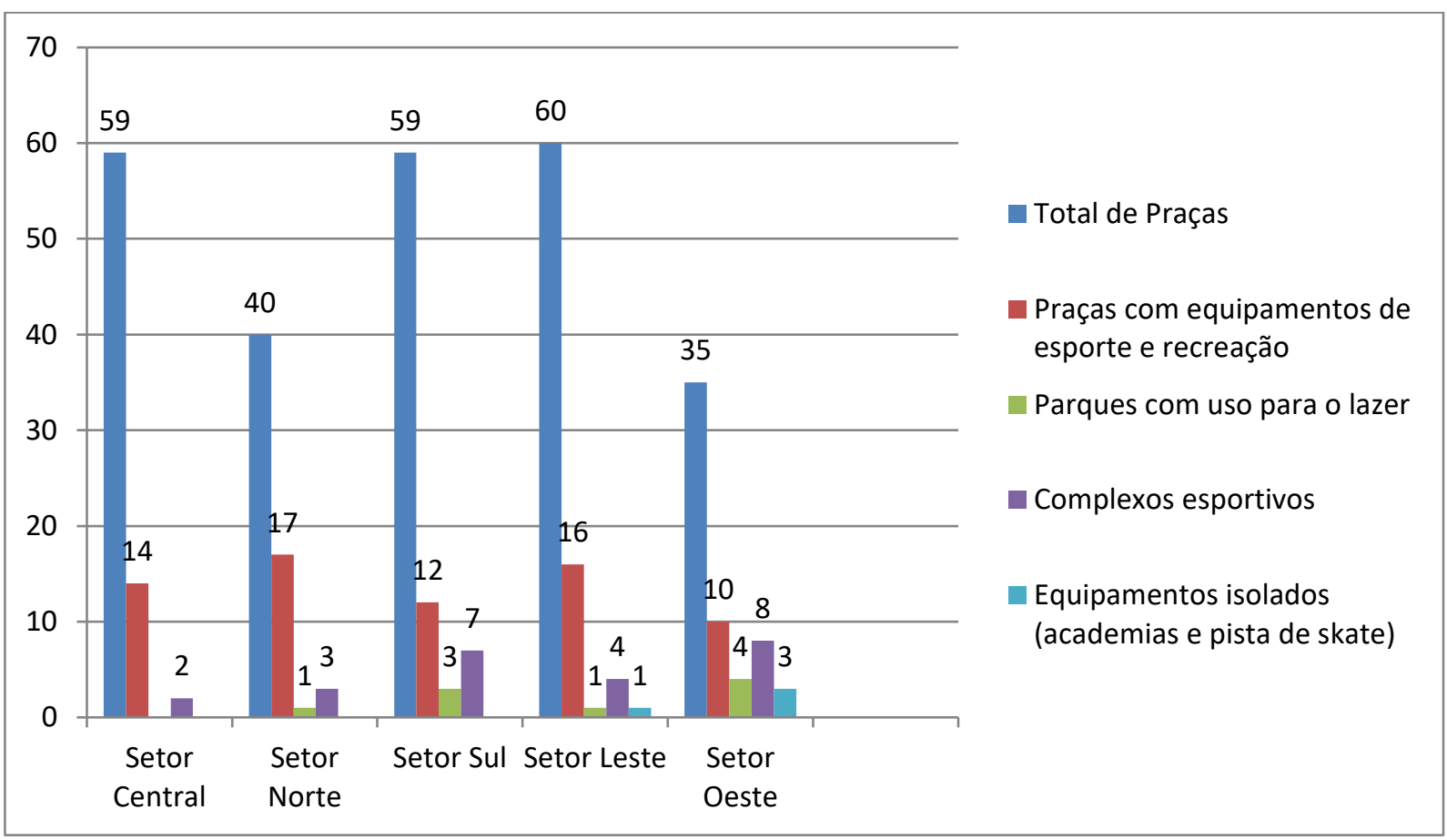

Fonte - Prefeitura de Uberlândia - Secretaria Municipal de Planejamento Urbano - Caderno Informativo 2018/2019, (2019). Organização: LUCAS, F. M. (2019).

Este gráfico corresponde a uma síntese da distribuição dos espaços/equipamentos públicos de esporte e lazer da cidade. Encontra-se presente o total de praças, os parques utilizados para o lazer, os complexos/centros poliesportivos com programação de recreação e esportes, alguns equipamentos isolados (pista de skate e academias ao ar livre), e as praças com equipamentos de lazer discriminados por setor.

Existe significativa concentração do total de praças nos setores, Central, Sul e Leste, já as praças que contam com equipamentos de esporte e lazer são mais expressivas nos setores, Norte, Central e Leste, respectivamente, conforme se visualiza na Figura 3. Observa-se uma diferença considerável em todos os setores da cidade no que se refere ao número total de praças e às praças dotadas desses equipamentos, com o predomínio das academias ao ar livre, dos parques infantis e das quadras de cimento ou areia. Desperta a nossa atenção, a discrepância presente expressivamente no Setor Sul (com 59 praças no total e apenas 12 com equipamentos), seguido do Setor Central (59 no total e $14 \mathrm{com}$ equipamentos) e do Setor Leste (60 no total e 16 com algum tipo de equipamento).

O documento analisado não contempla nenhuma pista de caminhada nas praças, estando tais espaços de circulação de pedestres vinculados oficialmente aos parques urbanos. Também não se encontram informações sobre a presença específica de áreas verdes e do mobiliário das praças, como bancos e calçamento, por exemplo. Foi possível visualizar cada uma das praças por meio de sua localização e, consequentemente, verificar a existência ou não de mobiliário e equipamentos de esporte e lazer a partir do recurso Street View do Google Maps.

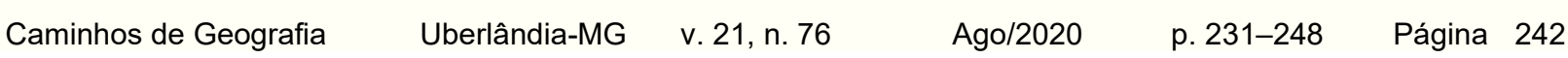


É relevante ressaltar, que a presença de equipamentos de esporte e recreação configura um importante indicador para diagnosticar a qualidade do espaço público das praças, sobretudo, no que tange à sua utilização para o lazer. No entanto, existem praças, que mesmo sem a presença desses equipamentos específicos são referência em termos de espaços lúdicos e de lazer para a comunidade local no seu dia a dia, ou mesmo para quem as frequente esporadicamente.

Observa-se que várias praças são compostas basicamente por "canteiros gramados", muito comuns em inúmeras rotatórias da cidade. Por outro lado, encontram-se praças principalmente na franja periférica que não existem efetivamente, com apenas o espaço reservado para a instalação destas conforme se verifica nas Figuras 4 e 5 a seguir. A primeira contempla uma praça localizada no Setor Sul da cidade (bairro Shopping Park), enquanto a segunda apresenta uma praça no Setor Leste (bairro Morumbi). Ambas estão presentes em áreas periféricas do tecido urbano, visivelmente caracterizadas por terrenos abertos, a primeira em um local com vegetação nativa de Cerrado, já a segunda, em um terreno parcialmente gramado e parte de terra, com um "campinho" ao lado de uma UBS - Unidade Básica de Saúde.

É importante mencionar que as praças ocupadas por canteiros gramados, ou por terrenos abertos sem qualquer tipo de paisagismo representam uma quantidade considerável em todos os setores da cidade. No entanto, especificamente estas últimas que contemplam terrenos abertos, encontram-se principalmente na periferia dos setores Sul, Oeste e Leste, respectivamente, com 13, 9 e 7 praças localizadas em cada setor.

É comum o espaço livre/aberto ou até a própria rua constituir opção de lazer, principalmente para crianças e adolescentes que habitam bairros mais periféricos sujeitos à exclusão social e desprovidos de espaços de lazer para seus moradores. Nesse sentido, a praça em destaque na Figura 5 com um "campinho de terra", provavelmente é apropriada e serve ao uso dos moradores do entorno, seja para jogar futebol, soltar pipa, etc. A Figura 6 destaca a localização das duas praças mencionadas, representando a vista aérea coletada a partir da imagem de satélite do Google Maps que retrata a malha urbana de Uberlândia.

Figura 4 - Vista aérea da Praça Frei Antonino Puglisi - Bairro Shopping Park, Setor Sul - 2020.

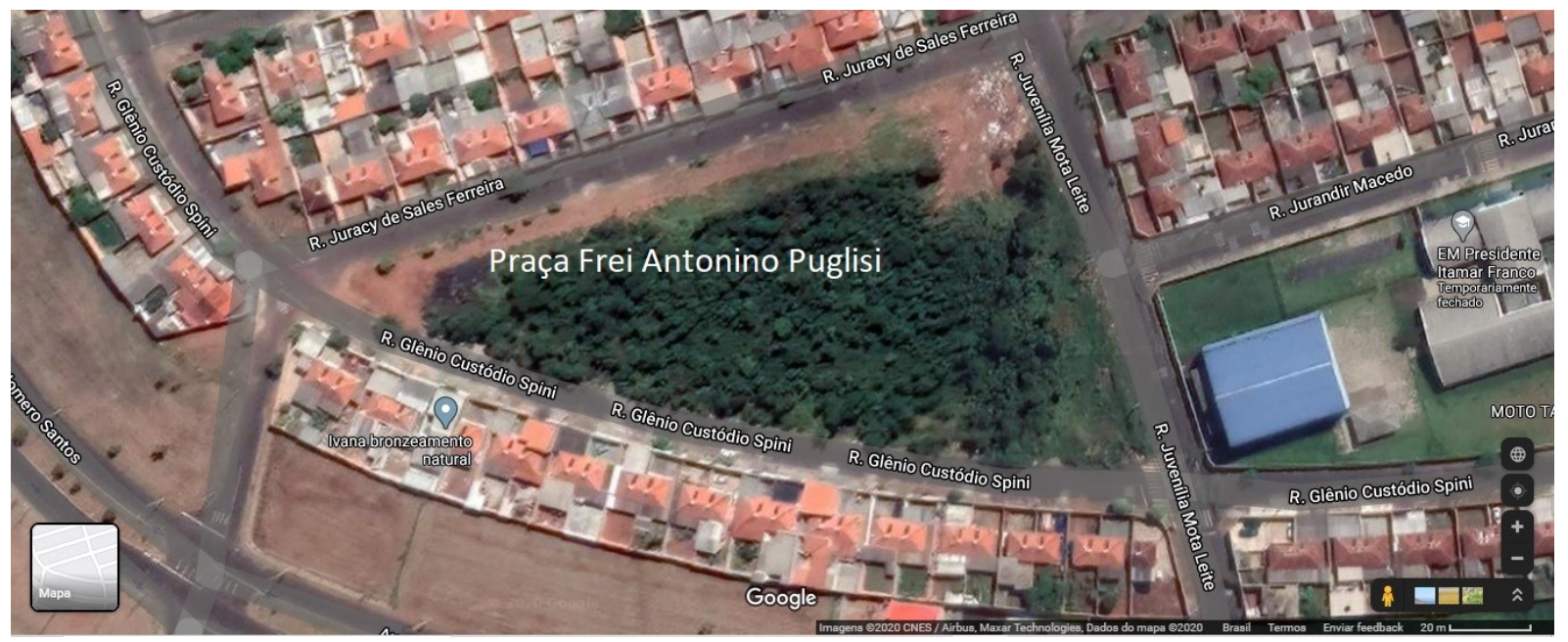

Fonte- https://www.google.com.br/maps. Acesso em 20/04/2020. 
Figura 5 - Vista aérea da Praça “Inonimada” - Bairro Morumbi, Setor Leste - 2020.

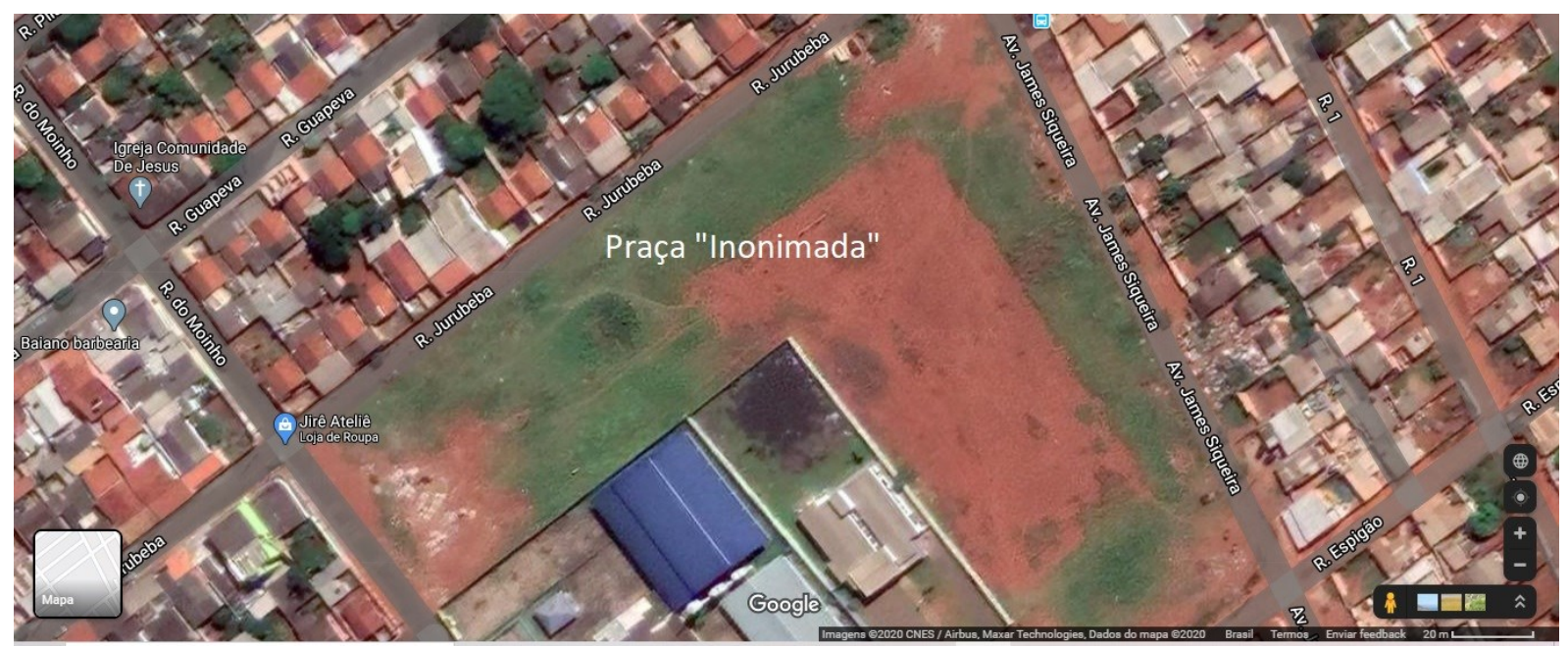

Fonte - https://www.google.com.br/maps. Acesso em 20/04/2020.

Figura 6 - Vista aérea da localização aproximada das duas praças na cidade de Uberlândia - 2020.

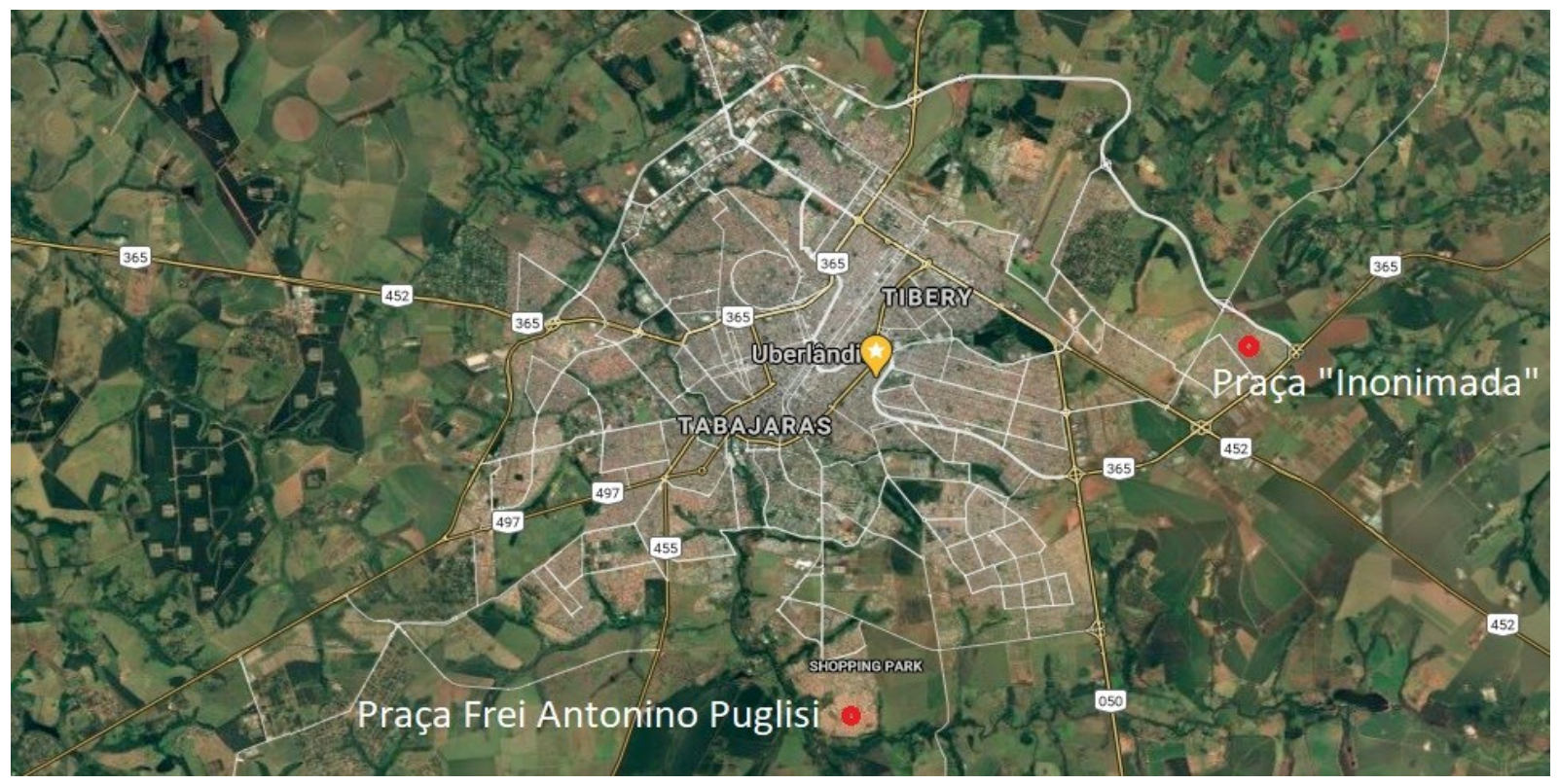

Fonte - https://www.google.com.br/maps. Acesso em 20/04/2020.

Os parques urbanos estão dispersos pela malha urbana, excetuando-se o Setor Central, em todos os outros existem ao menos um parque disponível para a atividade do lazer (Ver Figura 3). Os setores Norte e Leste possuem um parque em cada um deles, no entanto, ambos são de grande relevância e representam amplos espaços verdes e livres que integram o lazer na dinâmica intraurbana de Uberlândia, são eles respectivamente: o "Parque Victório Siquierolli" e o "Parque do Sabiá".

Os equipamentos de maior destaque para o uso da população são as pistas de caminhada e os parques infantis, existentes na maioria dos parques urbanos dos setores Norte, Sul, Leste e Oeste. As academias ao ar livre e mesas de jogos também são comuns, em contrapartida, a presença de museu ou núcleo ambiental, trilhas, ciclovias, campos e quadras de esportes são mais esporádicas. O mais expressivo em termos de diferentes opções ao usuário é o Setor Leste, com o Complexo "Parque do Sabiá" já mencionado, o qual conta com outros equipamentos além daqueles vistos nos demais setores, por exemplo: aquário, zoológico e parque aquático. 
Os complexos poliesportivos, centros esportivos e demais centros especializados que contemplam o esporte e a recreação contam com programas, escolinhas e oficinas que atendem à população no seu tempo disponível. Atendem crianças a partir dos 07 anos de idade, adolescentes, adultos e até idosos, concentrados nos setores Oeste e Sul de acordo com a Figura 3. Alguns se encontram presentes em áreas da cidade desprovidas de grande acessibilidade e opões de lazer em relação às áreas centrais.

Os chamados CEUs (Centros de Artes e Esportes Unificados) presentes em dois locais no Setor Sul, se destacam por concentrar em um mesmo espaço, uma série de programas e equipamentos de recreação e cultura. Podemos vê-los como complexos de lazer, os quais exercem a centralidade de uma praça e ofertam diversas atividades para a comunidade, fazendo-se necessário a ampliação de tais espaços ao longo dos diferentes bairros da franja periférica da cidade.

Ao considerar a Lei Complementar 023/2017, a qual revisa o Plano Diretor de Uberlândia, fica evidente o estímulo à atividade física e ao esporte como forma de lazer, relacionando tais atividades à qualidade de vida. Muitos dos incisos presentes no Art. 37, Seção II do Cap. IX (Políticas Públicas Sociais), ao se referirem às diretrizes do esporte e do lazer, priorizam a melhora dos núcleos e instalações esportivas, além do apoio às atividades voltadas para o esporte, com ênfase na ideia de deixar a cidade em um patamar de referência para atrair eventos e competições.

Isso se relaciona com as diretrizes que abordam o desenvolvimento do turismo apresentadas em outro capítulo do Plano Diretor, as quais se referem à necessidade de estruturar a cidade para atrair os grandes eventos, entre os quais, incluímos os esportivos. O esporte no âmbito desse plano, é visto como possibilidade de propiciar integração social, qualidade de vida e lazer, principalmente para as faixas etárias mais jovens. É perceptível, portanto, o foco nos espaços esportivos específicos (centros poliesportivos) que ofertam programação para crianças e adolescentes, com viés no rendimento esportivo.

Observa-se que o lazer vivenciado de forma mais livre e "descompromissada", não reduzido ao alto rendimento encontra-se mais presente nos parques urbanos e praças públicas, com destaque para equipamentos como as academias de ginástica, as quadras (de cimento ou areia) e os parques infantis, sobretudo, localizados em praças conforme a análise do Caderno Informativo 2018/2019.

No que diz respeito aos parques e as praças, tanto em relação à manutenção e/ou revitalização, bem como à presença de equipamentos e programação voltada para o lazer, não houve menção específica no Plano Diretor. Esperava-se encontrar informações nos Capítulos que tratam do desenvolvimento urbano e ambiental do município, sobretudo, no que trata do desenvolvimento ambiental, já que as praças e parques vinculam-se à Secretaria de Meio Ambiente e Serviços Urbanos. Dentre as diretrizes da política ambiental presentes no Art.14 do Cap.4, a relação possível de se estabelecer com a atividade do lazer, se refere à expansão e integração dos parques lineares urbanos ao longo dos fundos de vale. Colocando-os como uma possibilidade de urbanização, preservação e uso por parte das pessoas, o que inclui a ideia de viabilizar instrumentos que garantam recursos para a regularização de unidades de conservação e dos parques lineares ao longo dos córregos urbanos. (LEI COMPLEMENTAR Nº 023/2017 - PLANO DIRETOR, p.16-18).

Ao refletir sobre algumas questões que envolvem a presença dos parques urbanos e das praças como significativos espaços públicos nas cidades, Serpa (2007) nos apresenta com base em suas pesquisas que as praças e largos, escapam em geral à lógica eminentemente econômica, diferentemente dos parques que se tornaram imagens publicitárias dos poderes político e econômico. Podemos acrescentar que estes últimos, representam verdadeiros símbolos de determinadas gestões nos municípios, ainda atrelados aos interesses do capital imobiliário, carregam a valorização imobiliária do entorno, gerando até processos de segregação espacial e exclusão social. Para Serpa (2007, p.42),

a segregação de grandes parcelas da população reforça a ideia de que, no contexto urbano contemporâneo, o parque público é antes de tudo um espaço com alto valor patrimonial, contrariando o senso comum que idealiza esses equipamentos como bens coletivos e lugares de diversão, do entretenimento e da "natureza socializada".

No caso das praças, não existem referências específicas à programação de lazer ofertada, sendo detectado exclusivamente, o Programa "Adote uma Praça" junto à Secretaria de Meio Ambiente e Serviços Urbanos. Este, por sua vez, visa incentivar a adoção e manutenção de praças ou canteiros, com o intuito de ampliar, revitalizar e manter áreas verdes na cidade, contemplando parcerias com empresas privadas do município. É possível dizer que vem de encontro com as políticas praticadas em outras grandes e médias cidades brasileiras, onde fica claro que o poder público transfere sua responsabilidade com a manutenção dos espaços públicos. Por outro lado, a empresa que adota a 
praça atribui a propaganda do "verde urbano", criando uma imagem positiva de preocupação com a questão ambiental ao expor sua logomarca.

Após essa análise, constata-se que as praças, os parques urbanos e os complexos poliesportivos representam os principais espaços livres públicos disponíveis em Uberlândia, embora muitos bairros periféricos ainda careçam desses espaços. Reiteramos, portanto, a necessidade de inserir ao Plano Diretor um conjunto de diretrizes que contemplem a adequação dos parques e das praças para o lazer, de forma que propicie mais possibilidades para o cidadão usufruir estes espaços. Nesse sentido, é necessário incluir mais segurança, equipamentos/ mobiliário, além de programação cultural e esportiva que inclua o lazer e a recreação, sobretudo, nas praças públicas, já que estas são mais distribuídas espacialmente no espaço intraurbano.

Pensar o lazer a partir da presença de espaços qualificados, que propiciem satisfação e bem estar, é algo fundamental que deve ser almejado no planejamento territorial urbano, sendo cabível repensar as prioridades (a partir do envolvimento da população) que devem contemplar as políticas públicas urbanas, no intuito de enfatizar um maior acesso aos diferentes locais da cidade e amenizar as distorções presentes.

\section{CONCLUSÕES}

Apesar de fazer parte do processo mais amplo de reprodução do capital, vinculado fundamentalmente, ao consumo do espaço, o lazer precisa ser almejado como uma "brecha" necessária para a qualidade de vida nos centros urbanos. Não pode ser visto exclusivamente como algo padronizado, sendo necessário agregar em seu tempo/espaço diferenças em usos e formas de apropriação que representem espaços de liberdade.

Acreditamos que os espaços públicos livres e abertos, com possibilidade de serem dotados de áreas verdes, compreendam forte relevância para a vivência da cidade de forma mais espontânea na busca por qualidade de vida. Tais espaços são vistos com ênfase na transformação da paisagem, flexíveis na estruturação do território, funcional e espacialmente (TARDIM, 2008), com a necessidade de um planejamento que atenda efetivamente ao cidadão. O lazer, nesta ótica, deve ser almejado como a produção de cultura e de atividades pró- ativas ou contemplativas.

De uma forma geral, observa-se que as políticas públicas de lazer analisadas em Uberlândia se encontram intimamente relacionadas à programação esportiva, onde o lazer associado ao esporte representa um fator de inclusão social, sobretudo, de crianças e adolescentes ao levar em conta a programação presente. Com relação aos espaços de lazer, é necessário enfatizar a necessidade de haver uma distribuição mais equitativa dos espaços livres públicos dos parques e das praças ao longo da cidade. Especialmente as praças, vistas por de De Angelis et al. (2005) como as "senhora(s) dos espaços públicos", as quais normalmente estão mais próximas do cotidiano da população se comparado aos parques, detectando-se contraditoriamente, uma razoável quantidade de praças em bairros da franja periférica que são instituídas oficialmente, mas na prática são espaços abertos não urbanizados e precários.

A presença de estratégias para favorecer a utilização do espaço público é válida, desde que isso contemple os reais interesses dos moradores das diversas localizações da malha urbana das cidades. O problema, segundo Serpa (2007, p.76), é que em muitas das vezes, na instalação de determinados espaços públicos, "os usuários raramente são objeto de grande interesse por parte dos agentes que viabilizam a implantação", principalmente quando se tratam de espaços que tendem a se tornar objeto visual que funcione como peça publicitária das administrações.

É necessário refletir acerca da necessidade de (re) aproximação da população local, na busca de uma mistura que contemple o resgate da cultura popular, bem como a presença de áreas verdes, mobiliário e equipamentos de lazer bem cuidados. Para que isso ocorra, é necessário pensar em uma efetiva participação popular, sejam na escolha das áreas, equipamentos etc. que atendam aos interesses da comunidade, bem como no que tange à utilização de fato dos espaços de lazer através de sua ocupação, o que passa por uma verdadeira ação comunitária. 


\section{AGRADECIMENTOS}

Agradeço à Secretaria de Planejamento Urbano do município de Uberlândia por disponibilizar os arquivos e documentos para a análise, entre estes, o Plano Diretor atualizado e o Caderno Informativo 2018/2019, consultado para visualizar a oferta dos espaços livres públicos de lazer da cidade. Agradeço ao Instituto Federal do Triângulo Mineiro pelo suporte ao desenvolvimento da pesquisa.

\section{REFERÊNCIAS}

ANDRADE, José Vicente. Lazer: princípios, tipos e formas na vida e no trabalho. Belo Horizonte: Autêntica, 2001.

BARBOSA, Lívia. Sociedade de Consumo. Rio de Janeiro: Ed. Jorge Zahar, 2004.

BESSA, Kelly Cristine. Reestruturação da rede urbana brasileira e cidades Médias: o exemplo de Uberlândia (MG). Caminhos de Geografia 24(16) p.268 - 288, out/2005. Disponível em http://www.ig.ufu.br/revista/caminhos.html. Acesso em 12/04/2019.

CADERNO INFORMATIVO 2018/2019. Secretaria Municipal de Planejamento Urbano: Uberlândia, 2019.Disponívelemhttp://www.uberlandia.mg.gov.br/prefeitura/secretarias/planejamentourbano/politica s-publicas/. Acesso em 01 de agosto de 2019.

CARLOS, Ana Fani A. O Consumo do espaço. In CARLOS, Ana Fani A. (Org.). Novos Caminhos da Geografia. São Paulo: Contexto, $3^{a}$ ed., 2001.

O Espaço Urbano: Novos Escritos sobre a Cidade. São Paulo: FFLCH, 2007(a), 123p.

O lugar no/do mundo. São Paulo: FFLCH, 2007(b), 85p.

Da "organização" à "produção" do espaço no movimento do pensamento geográfico. In $\overline{\mathrm{CARLOS}}$, Ana Fani A.; ŞOUZA, Marcelo Lopes de; SPOSITO Maria Encarnação B. (Org.). A produção do espaço urbano: agentes e processos, escalas e desafios. São Paulo: Contexto, 2011.

CASTRO, Iná E. O problema da Escala. In CASTRO, Iná E., GOMES, Paulo C. C., CORREAA, Roberto Lobato (Organizadores). Geografia: Conceitos e Temas. - $2^{\mathrm{a}}$ ed. - Rio de Janeiro: Bertrand Brasil, 2000.

CHAUÍ, Marilena. O Direito à Preguiça (Introdução - p.9 - 56). In LAFARGUE, Paul. O Direito à Preguiça. São Paulo: Hucitec e Unesp, 2000.

COCOZZA, Glauco de P. e OLIVEIRA, Lucas M. Forma urbana e espaços livres na cidade de Uberlândia (MG), Brasil. Paisagem e ambiente: ensaios - n. 32 - São Paulo: p. 9 - 32, 2013. Disponível em http://www.revistas.usp.br/paam/article/view/88070. Acesso em 20/06/2019. https://doi.org/10.11606/issn.2359-5361.v0i32p9-32

DAMIANI, Amélia L. Turismo e lazer em espaços urbanos. In RODRIGUES, Adir B. (Org.) Turismo Modernidade - Globalização. São Paulo: Hucitec, 1997.

DE ANGELIS, Bruno L. D. et al. Praças: história, usos e funções. Maringá: EDUEM, 2005.

DUMAZEDIER, Jofre. Sociologia Empírica do Lazer. São Paulo: Perspectiva -SESC, 1999.

. Lazer e cultura popular. São Paulo: Perspectiva, 2001.

FONSECA, Maria de Lourdes P. Padrões sociais e uso do espaço público. Caderno CRH, Salvador, v. 18, n. 45, p. 329-500, 2005.

GOMES, Paulo César da C. A condição urbana: ensaios de geopolítica da cidade. Rio de Janeiro: Bertrand Brasil, 2002, p. 129-191.

HARVEY, David. A produção capitalista do espaço. Tradução Carlos Szlak. Coordenação Antônio Carlos Robert Moraes. São Paulo: Annablume, 2005.

JESUS, Gilmar Mascarenhas. A cidade moderna e as técnicas: uma nova espacialidade do tempo livre. In: Anais do Encontro da Comissão de Geografia Cultural da União Geográfica Internacional, Rio de Janeiro, 2003.

LEFÉBVRE, Henri. La Vida Cotidiana en el mundo moderno. $3^{\text {a }}$ ed. - Madrid: Alianza Editorial, 1984. . O Direito à Cidade. São Paulo: Centauro, 2001. 
LEI COMPLEMENTAR N 023/2017 - Revisão do Plano Diretor do Município de Uberlândia, 2017. Disponível em https://www.uberlandia.mg.gov.br/prefeitura/secretarias/planejamento-urbano/planodiretorl. Acesso em 10/09/2019.

MARCELLINO, Nelson C. Lazer e Educação, $3^{a}$ ed. - Campinas - SP: Papirus, 1995.

Estudos do lazer: uma introdução. $2^{\mathrm{a}}$ ed. - Campinas - SP: Autores Associados, 2000. Lazer e Humanização. $7^{\mathrm{a} e d .}$ - Campinas - SP: Papirus, 2003.

MEDEIROS, Ethel B. O Lazer no planejamento urbano. $2^{\mathrm{a} e d}$. - Rio de Janeiro: Ed. Fundação Getúlio Vargas, 1975.

MUÑOZ, Francesc. Urbanalización: En el Zoco Global de las Imágenes Urbanas. In CidadesComunidades e Territórios, Dez. 2004, n9, p.27-38. Disponível em http://revistas.rcaap.pt/cct/article/view/9198/6645. Acesso em 26/06/2018. https://doi.org/10.7749/citiescommunitiesterritories.dez2004.009.art02

PADILHA, Valquíria. Se o trabalho é doença, o lazer é remédio? In MULLER, Ademir e DA COSTA, Lamartine P. (Org.) Lazer e Trabalho: um único ou múltiplos olhares? Santa Cruz do Sul: EDUNISC, 2003.

Consumo e lazer reificado no universo onírico do shopping center. In: PADILHA, Valquíria. (Org.). Dialética do lazer. São Paulo: Cortez, 2006. p. 126-155.

PARKER, S. A sociologia do lazer. São Paulo: Zahar, 1978.

ROLNIK, Raquel. O lazer humaniza o espaço urbano. In: SESC SP. (Org.). Lazer numa sociedade globalizada. São Paulo: SESC São Paulo/World Leisure, 2000.

SANTOS, Milton. O Espaço do Cidadão. São Paulo: Nobel, 1987.

Metamorfoses do Espaço Habitado - Fundamentos Teóricos e Metodológicos da Geografia. São Paulo: Hucitec, 1988.

A Urbanização Brasileira. São Paulo: Hucitec, 1993.

SERPA, A. O espaço público na cidade contemporânea. São Paulo: Contexto, 2009.

SOARES, Beatriz R. et al. Dinâmica urbana na bacia do rio Araguari (MG) - 1970-2000. In LIMA, S. C. , SANTOS, R. J. (Org.). Gestão Ambiental na Bacia do Rio Araguari: rumo ao desenvolvimento sustentável, Uberlândia: UFU/IG, Brasília: CNPq, 2004, p.125-161.

SPOSITO, Maria Encarnação B. O chão em pedaços: urbanização, economia e cidades no Estado de São Paulo. Tese (Livre Docência), FCT/ UNESP - Presidente Prudente - SP, 2004.

A produção do Espaço Urbano: Escalas, diferenças e desigualdades socioespaciais. In $\overline{\mathrm{CARLOS}}$ Ana Fani A.; SOUZA, Marcelo Lopes de; SPOSITO Maria Encarnação B. (Org.). A produção do espaço urbano: agentes e processos, escalas e desafios. São Paulo: Contexto, 2011.

TARDIM, Raquel. Espaços livres: sistema e projeto territorial. Rio de Janeiro: 7 Letras, 2008.

VILLAÇA, Flávio. Espaço intra-urbano no Brasil. São Paulo: Studio Nobel, 2001.

Recebido em: 27/02/2020

Aceito para publicação em: 26/05/2020 